\title{
Food security in South Africa-first steps toward a transdisciplinary approach
}

\author{
S. Drimie • M. McLachlan
}

Received: 2 November 2012 / Accepted: 17 January 2013 / Published online: 5 February 2013

(C) The Author(s) 2013. This article is published with open access at Springerlink.com

\begin{abstract}
The Stellenbosch University Food Security Initiative provides a platform on which a range of research projects has been developed, spanning different faculties and departments, including the health sciences, agricultural sciences, engineering, and the social sciences. Drawing on a selection of these projects, some of which are published in a special section of this issue of Food Security, the paper highlights key emerging findings and their implications for future work in this field in South Africa. It incorporates a range of perspectives on food security in the country, highlighting different dimensions of the subject. The paper argues that a systemic approach is required to address food insecurity in South Africa, combining rigorous disciplinary and interdisciplinary research with effective approaches to research-policy linkages and social learning. The review concludes that such an approach should be institutionalised at Stellenbosch University to inform the emergence of a resilient food system for the region in the $21^{\text {st }}$ Century.
\end{abstract}

Keywords Food security · Transdisciplinary research . South Africa

\section{Introduction}

Stellenbosch University's Food Security Initiative (FSI) ${ }^{1}$ intends to contribute to the emergence of a resilient, sustain-

\footnotetext{
${ }^{1}$ We gratefully acknowledge the financial support of the Stellenbosch University Hope Project for the research included in this special section.

S. Drimie $\cdot$ M. McLachlan $(\bowtie)$

Division of Human Nutrition, Faculty of Medicine and Health

Sciences, Stellenbosch University, Francie Van Zijl Avenue,

Tygerberg, Tygerberg 7505, South Africa

e-mail: millam@sun.ac.za
}

able food system ${ }^{2}$ for Southern Africa, by interrogating and reconceptualising the food security challenge and creating new models of practice. This is being done through the integration of findings from in-depth research on key issues in the food value chain, collaboration across disciplinary boundaries, capacity building and systematic impact assessment. These ambitious objectives provided the platform on which several research projects were developed, starting in 2009. The research programme spans different faculties and departments including health sciences, agricultural sciences, engineering, and the social sciences. Drawing on a selection of the research emerging from the initiative, this review paper highlights key emerging findings and their implications for future work in this field. In particular, the paper argues that the complexity of the food security challenge facing the region demands that the FSI adopt an explicit transdisciplinary approach combining in-depth disciplinary research on defined issues with integrated research programmes that span disciplines and sectors, engage stakeholders, and give particular attention to joint learning. Given the existence of the Transdisciplinary $\mathrm{PhD}$ programme on Sustainability (TsamaHub), and the Institute for Advanced Studies (STIAS), among others, at Stellenbosch University, the FSI is well positioned to take up such a challenge and establish an entity to develop and pursue this agenda.

Recent reviews document the failure of existing strategies in South Africa to deal adequately with the complex challenges currently facing the country's food system (Altman et al. 2009; Chopra et al. 2009; McLachlan and Thorne 2009). Given the

\footnotetext{
${ }^{2}$ The food system is broadly defined to include the entire food value chain, from agricultural input markets, through food production, processing, distribution, retail, consumption and waste handling, as well as regulatory functions and support services. While the focus is on the food system, it is recognized that the environmental system and the health/disease system are in dynamic interaction with the food system at various levels (see Hammond and Dubé 2012).
} 
rapidly changing context that involves both "long wave stresses" such as climate change, and "short wave shocks" such as food price volatility, solutions that may have worked in the past are no longer adequate. Risk is driven upwards by intensifying conditions of political, socio-economic and environmental vulnerability, which are often silent. As was the case in previous food price crises, which put the livelihoods of millions in Southern African at risk, these conditions, coupled with external threats, could again trigger widespread suffering and deepen food insecurity (Drimie and Casale 2009).

Understanding the underlying causes of this situation requires untangling the knot of "multiple stressors", which lie at the root of food insecurity ${ }^{3}$ (Drimie and Casale 2009). Thus, as demonstrated by this special section of the journal, the reasons for the persistence of hunger and malnutrition in South Africa are complex and interrelated, spanning environmental, health, economic, socio-political and agro-food issues, include increasing unemployment, food price volatility, HIV and AIDS, drought conditions in South Africa and major trading partners, a decrease in government support for agriculture and persistent high levels of urban and rural poverty.

These challenges make achieving the constitutional right of all South Africans to adequate food difficult, despite national and international commitments to meeting these rights. Government capacity is often highlighted in the context of failing service delivery as the major underlying reason why many rights remain unrealised (Chabane 2012; Hunter et al. 2003). However, improved service delivery alone will not result in realising the right to food, given the prominent role of the private sector in the provision of food. Different stakeholders in the food system have widely different perspectives and interests and challenging structural issues such as power differentials among them remain largely unexamined (Vogel et al. 2007). Furthermore, the conceptual underpinning and empirical evidence base for perspectives and approaches vary widely, and are often more implicit than explicit. This makes rational discourse among stakeholders from different disciplines, sectors and levels difficult, and prevents them from working together effectively to find innovative ways to respond to food security challenges (Ramalingam et al. 2008; Regeer and Bunders 2009).

Real-world solutions require dismantling some of the boundaries between disciplinary and programmatic fields. Innovative ways are required to facilitate the substantial changes required at different levels of the food system. These changes range from building the ecological and social resilience of the food system through, for example, the

\footnotetext{
${ }^{3}$ Such stressors can include any changes that manifest as shocks (e.g., floods, job losses, death) or gradual changes (e.g., land degradation, deterioration of health care systems).
}

sustainable production of food that reduces biodiversity loss, greenhouse gas emissions, water use and water pollution, along with the improvement of the political and economic governance of the system to increase accessibility, utilisation and stability of food.

Further, to realise the vision of a food-secure South Africa, there is need for security at all scales-from the individual through to the household right up to the region and continent. This needs to meet the challenges of a fastchanging reality including climate change, urbanisation, population growth and environmental sustainability. The food system will essentially have to deliver more human value to those who need it most, with the least environmental harm. This vision resonates with the following definition of food security:

"Food security exists when every person has access to sufficient food to sustain a healthy and productive life, where malnutrition is absent, and where food originates from efficient, effective, [equitable] and low-cost food systems that are compatible with sustainable use of natural resources" (IFPRI 1995, p.50).

The recently launched National Development Plan (NDP) (National Planning Commission 2012), provides an innovative framework to begin to inform action required across society to deal with pervasive hunger. The NDP makes several arguments that resonate with international literature in its appraisal of what it will take to eradicate food insecurity. The range of proposed interventions requires engaging the entire food system, as well as linkages with the education and health systems. The NDP proposals align with a systems approach, as engaging each proposal as an isolated, stand-alone issue is likely to result in fragmentation, unintended consequences and inefficiency. Therefore, the NDP calls for collaboration between government, the private sector, civil society and citizens to establish "self sustainable" local food systems that would underpin universal access and utilisation over time. Such an approach is envisaged to reduce hunger and poverty, increase agricultural development and address malnutrition, which will in turn contribute towards skills development and improve inclusive economic growth and job creation.

\section{Adopting systemic and transdisciplinary approaches}

Achieving this vision will require innovative approaches to research, policy dialogue and practice that recognise relationships and feedback loops in systems, and how they affect food security. Such approaches need to emerge and be led from African institutions, including universities, in collaboration with international partners, to build the capacity and leadership to drive sustainable solutions at a number 
of levels. As highlighted in an influential series of recent reports suggesting possible solutions to the interwoven food security crisis, investment in new knowledge and innovation is required to build this capacity (IAASTD 2009; Royal Society 2009; Foresight 2011; Godfray et al. 2010) Such an approach would fundamentally challenge current arrangements by moving beyond the strictures of disciplines whilst retaining scientific excellence.

The complex food system challenges relating to these areas cannot be understood and addressed using mono-disciplinary approaches only. Food security is a transdisciplinary challenge and requires transdisciplinary responses. From the papers discussed here, the support of strong disciplinary research remains important for addressing some of the challenges of food insecurity, while the integration of research and results from several disciplines would add new insights and contribute to novel solutions. However, narrowly disciplinary or academic modes of research or learning - and attempts to integrate such learning - cannot deal adequately with the challenges of food insecurity, nor is it seen as appropriate by many societal actors, including policy makers, as a means for finding solutionsand would therefore not be acceptable to them (Jahn 2008).

There is therefore a strong argument for developing and sharing interdisciplinary and transdisciplinary approaches to strengthen research and action on food security across South Africa and more broadly across the African continent. Transdisciplinary approaches, particularly in research, are a scientifically sound way of engaging society, which produces socially relevant as well as new scientific knowledge and insights. This research and knowledge production is a hybrid, combining learning, research, and application and facilitates the development of competencies and skills necessary for understanding and creating sustainable transitions (Klein et al. 2001).

Transdisciplinary approaches correspond with the idea that not only is scientific knowledge relevant for the resolution of persistent societal problems such as food insecurity, but that social knowledge or experiential knowledge is also important (Regeer and Bunders 2009). Researchers will be challenged to cross the boundaries between human and natural sciences to generate results that could not be attained using a disciplinary or sectoral approach alone. The different perspectives on the issue come together in a learning process whereby, in the course of the interaction, implicit knowledge is made explicit, and new knowledge is construed, shared and tested. It can thus be understood as a method for practically-oriented and solution-focused knowledge creation in heterogeneous collaborations.

Put differently, transdisciplinary research actively intervenes in the societal process of defining problems concerning states of affairs and interpretations of specific sets of knowledge (Jahn 2008). So at a particular point in time, a specific research project focusing on food security within a particular setting will be "frozen" in order to make it accessible to scientific treatment under controlled conditions in the course of the process of research. What this means is that actors who are affected by the problem-small-scale farmers in Jozini, women traders in Johannesburg or fishing communities near Saldanha Bay, as examples - will be drawn into the research process. Secondly, it means that the problem must be turned into a scientifically valid question in the course of the exchange between these concerned societal actors and the scientific actors. This allows for clarification around interpretation, claims of validity and conflicts of interest.

Another innovation within transdisciplinary approaches comes from linking cutting edge natural science and technology with cultural and social needs and requirements. Food insecurity is an example of a problem in which social action and ecological effects are tightly linked, so that the borderline between society and nature is blurred (Jahn 2008). This complexity means causal processes remain unclear, running along different spatial, temporal and social scales - from local to global, from current events to longterm consequences, from action in everyday contexts to the policies of worldwide regimes and multinational organizations. A stunted child in the Zululand district is linked through a complex chain to Canadian seed companies and British aid agencies, with other multiple players and structures engaged in complex relationships and feedback loops throughout the system.

These processes should be integral to the research projects that unfold under a broader programme and will be core to training and support offered at various levels. Much of the capacity will be built through the application of transdisciplinary approaches, as scientists and other societal actors cooperate and co-learn to overcome the disjuncture between knowledge production, on the one hand, and the demand for knowledge to contribute to the solution of societal problems, on the other hand. This engagement will build new knowledge and solutions that will work at the root of hunger in many settings. Through scientists entering into a process of mutual learning with relevant stakeholders across sectors in society, the research becomes part of broader societal processes, contributing explicit solution-orientated approaches that combine society and science (Hirsch Hadorn et al. 2008). This framework will enable problem solving through reflection, transforming attitudes, developing personal competences and ownership, and through this build the capacity of those involved, particularly in terms of leadership.

\section{Food and nutrition security in South Africa}

A brief review of the food security situation in South Africa, which by the definition above includes nutrition, illustrates these complexities and demonstrates the importance of taking a participatory and transdisciplinary approach to 
addressing the food and nutrition security challenges. At a general level, the food security situation in South Africa mirrors the global picture in that sufficient aggregate availability of food does not translate into adequate accessibility for all people. While South Africa is currently food secure at a national level in terms of aggregate food availability, maintaining a secure national food supply for the medium to long term will require support for the farming sector that is predicated on sustainable resource use and enabling regional trade policies. As an example of an effective food security strategy to maintain adequate food availability at the national level, Vink (2012) argues that the focus should be on a positive trade balance for primary and processed agricultural products from within the southern African region, rather than to strive to achieve food self-sufficiency in staple crops.

The food security situation at household and community levels is far less positive, as articulated by De Cock et al. in this special section of the journal. Although infrequent and incomplete in scope, national level nutrition surveys indicate that about $24 \%$ of children under 5 years of age are stunted ${ }^{4}$; and approximately $57 \%$ of children under 5 years of age show signs of wasting ${ }^{5}$ (Ardington and Case 2009). Micronutrient malnutrition, particularly deficiencies of Vitamin A, iron and zinc, affects the health, growth and learning ability of young children, and ultimately, the productivity of the population. At the same time, and often in the same communities and households, overweight and obesity ${ }^{6}$ contribute significantly to the incidence of chronic diseases, including diabetes, cancers and coronary artery disease (Puoane et al. 2002; Ardington and Case 2009).

The 2005 National Food Consumption Survey (NFCS) reports that despite the overall growth of the South African economy, one out of two households (51.6\%) experienced hunger, approximately one out of three was at risk of hunger and only one out of five appeared to be food secure (Labadarios et al. 2008). The prevalence of households experiencing hunger was highest in the Eastern Cape, Northern Cape and Limpopo provinces. Being at risk or experiencing hunger was negatively correlated with socioeconomic factors, including household monthly income,

\footnotetext{
$\overline{{ }^{4} \text { The stunting }}$ rate, regarded as a measure of chronic malnutrition, refers to the percentage of children with height-for-age less than -2 standard deviations of the WHO Child Growth Standards median (http://www.who.int/nutrition/publications/severemalnutrition/ 9789241598163_eng.pdf accessed 21 October 2012).

${ }^{5}$ Wasting rate, a measure of acute malnutrition, refers to the percentage of children with weight-for-height less than -2 standard deviations of the WHO Child Growth Standards median.

${ }^{6}$ WHO (2012) measures overweight and obesity in adults in terms of body mass index, which is defined as a person's weight in kilograms divided by the person's height in meters squared $\left(\mathrm{kg} / \mathrm{m}^{2}\right)$. The cut-off points are as follows: Overweight: BMI greater than or equal to 25 ; obesity, BMI greater than or equal to 30 .
}

weekly expenditure on food and employment status. Even in the rural areas, most households were net deficit food producers, as their access to food was partially or wholly reliant on household income. As a result, food security is directly or indirectly linked to access to cash to purchase food (Chopra et al. 2009).

Although often considered a rural phenomenon, food insecurity also occurs in urban areas in South Africa. The African Food Security Urban Network (AFSUN) conducted a systematic eleven-city baseline survey in nine southern African countries in order to understand the state of food insecurity in poor areas of the cities (Crush and Frayne 2010). Using measurements adapted from the Food and Nutrition Technical Assistance project (FANTA), the survey found $76 \%$ of sampled households to be moderately or severely food insecure. Almost half (49.6\%) of total expenditure by households sampled was spent on food, reflecting a widespread pattern that poorer households spend a greater proportion of their income on food. Further, the overlay of food insecurity and the HIV epidemic in urban informal areas are raising significant challenges for urban development processes (Vearey et al. 2010).

Food insecurity is thus not an exceptional, short-term event but a chronic threat for a large proportion of South Africa's population, which is related to inadequate food, health, and caring behaviours and also grounded in specific economic, social, political and institutional aspects of South African society. For example, Greenberg (2006, p.13) argues that "the ghettos (rural and urban) created by the segregationist system of apartheid ... continue to underpin the economic and social, if not political, structure of the country, exacerbating differentiation at a household leveland even within households - so that those without effective command over resources may be food insecure even in areas where there is local-level security". The underlying causes and structural factors inherited from the past continue to prevent people from participating actively in the economy, are often contested, and pose difficult policy challenges $(\mathrm{Du}$ Toit 2011).

Over the past 5 years there has been an increase in attention given to food security issues, both globally and in South Africa. Several agencies within the state, civil society, academia and the private sector have embarked on efforts to document, analyse and find solutions to the problem. For example, food insecurity was high on the agenda in the discourse leading up to the national elections of 2008. This emphasis on food security in policy dialogue was supported by initiatives at institutions such as the Development Bank of Southern Africa (DBSA) (see McLachlan and Thorne 2009) and the Human Sciences Research Council (HSRC) (Altman et al. 2009).

The Department of Agriculture, Forestry and Fisheries (DAFF) is developing a Food Security Policy premised on 
the Bill of Rights in the Constitution, which is intended to be ready for public comment towards the end of 2012. As emphasised earlier, the National Development Plan, recently endorsed by Parliament, also addresses food security, but goes beyond an agricultural focus by making recommendations for expanding the community works programme for rural infrastructure development, ensuring all eligible households have access to social grants and implementing measures to ensure that vulnerable groups (particularly the elderly and chronically ill) have access to nutritional services (National Planning Commission 2012).

These promising frameworks, particularly the vision articulated in the NDP, require a clear understanding of the structural underpinnings of food insecurity and how to respond to the extent of the challenge. Without a comprehensive picture of food insecurity in South Africa, many of these initiatives may well remain as well intentioned but ineffective responses.

We would argue that a transdisciplinary approach, such as that promoted by the FSI, would go a long way towards building this more complete picture and understanding. This special section of Food Security provides a survey of some of the research that is emerging from FSI that can underpin future understanding and action on food security in South Africa. The following papers provide insights on issues of measurement and monitoring, seasonality and diet diversity, as well as the contribution of subsistence farming, indigenous plants, wild fowl and mariculture to food security.

\section{Measuring and monitoring}

The complexity of the subject of food security/insecurity raises the challenge of measuring and monitoring it in order to systematically understand and address it. As with most concepts, food security is hard to measure and is contextspecific (Vink 2012). The various papers constituting this special section of the journal demonstrate the range of ideas that make up what is understood to be food security. De Cock et al. (this issue) argue that food security is multidimensional in nature, which makes accurate measurement and policy targeting challenging. Their paper summarises various methods to assess food security at the household level that have been used in the country, including the NFCS, the (short-lived) Food Insecurity and Vulnerability Information and Mapping System (FIVIMS), the General Household Survey (GHS), the Income and Expenditure Survey (IES), the Community Survey, the South African Social Attitudes Survey, and the Labour Force Survey.

Unsurprisingly these investigations obtained different results: the 1995 IES indicated that around $43 \%$ of households (rural and urban) were subject to food insecurity, which resonated with the figure of half the population argued by the 2005 NFCS. In contrast, the GHS of 2007 estimated that $10.6 \%$ of adults and $12.2 \%$ of children were sometimes or always hungry (Jacobs 2010). Most recently the GHS puts the number of South Africans who are "vulnerable to hunger" at $11.5 \%$ (StatsSA 2012).

Several authors point out that this variation in the data is because each survey probes a different dimension of food security such as food expenditure, hunger or household food production, thereby using different indicators or measures (Altman et al. 2009; Jacobs 2009). The study by De Cock et al. (2013) provides a useful example of how the range of dimensions constituting food insecurity can be measured. Applying a blend of both qualitative and quantitative methods, this approach could be replicated to produce a comprehensive picture of hunger in South Africa.

Data was gathered across five districts in Limpopo province. The findings showed that $52 \%$ of the rural households sampled declared themselves to be severely food insecure while $32 \%$ lived on the equivalent of less than $\$ 1$ a day. Female-headed households tended to be more vulnerable to food insecurity than male-headed households. This resonated with another recent study with a broader ambit which concluded that women in rural areas were the most vulnerable to hunger. Across 27 countries in sub-Saharan Africa, rural women were $68 \%$ more likely to be malnourished, compared with their urban counterparts (Uthman and Aremu 2008). Agricultural development agendas often fail to take account of the different roles of men and women, and the inequities between them, leading to women's contributions being overlooked and underestimated in development strategies (World Bank 2008).

The study by De Cock et al. (2013) revealed that only $14.5 \%$ of all respondents declared themselves to be food secure. Even if these data were exaggerated and negatively biased, they suggest that the food insecurity situation remains extremely serious. This is in direct contrast to the latest GHS findings, which reported that Limpopo had better access to food compared to any other province-including the "wealthier" ones such as Gauteng and the Western Cape (StatsSA 2012). Once again, these studies revealed the complexity of measurement even when using similar instruments. These comparisons call for additional investigation into why the measurements differ so greatly and for exploring how to bring them to a common understanding. Without such commonality, resources to address the problem may easily be misdirected.

\section{Dimensions of food security in rural South Africa: seasonality and diversity}

The study by De Cock et al. (2013) also revealed an important dimension of food insecurity, namely seasonality. 
Data concerning the specific months in which households were hungry indicated that the largest proportion of households $(25.9 \%)$ experienced hunger during January, followed by June (17.2\%), February (16.2\%), July (15.5\%) and December $(15.2 \%)$. These findings echoed the 2005 FIVIMS survey conducted in Sekhukhune, a district of Limpopo. That study found that most of the households experienced a lack of food or money during January and February (Rule et al. 2005), the immediate post-holiday and pre-harvest period. Factors explaining this included a household budget deficit caused by high spending patterns over the festive season, a lack of income during the festive season due to vacation leave and funds being allocated to other cost items, such as school fees and school uniforms, in January.

Another important story emerged with respect to dietary diversity, an important but often overlooked component of food security. The Household Dietary Diversity Score (HDDS) was calculated for all surveyed households. The results showed that households had an average HDDS of 6.7 out of the 9 food groups eaten, which revealed that the average household had a diverse diet, a pattern reflected across the different districts and municipalities. These data supported the findings of the 2005 NFCS in that most households procured rather than produced most of their food. Farming, whether subsistence of commercial, is not a major source of the most widely consumed food items, including the staple, maize.

Multivariate analyses were then used to identify the main household characteristics that influenced a household's food security status. These determinants were grouped into i) human capital, entailing mainly education, household size and gender of the household head, ii) household income, iii) type of employment and iv) dependency on grants and gifts. From these findings, the research team argued that the promotion of rural education could contribute significantly to improving food security levels, as education was positively correlated with food security. To address food insecurity, policies should also be focused on creating an open, viable and dynamic rural labour market with sustainable employment opportunities.

Through multivariate analysis and comparison of indicators, the research provides a useful overview of instruments that can contribute to providing an in-depth analysis of food security. It also reiterates the importance of using a combination of qualitative and quantitative analyses to understand the underlying causes of hunger, particularly if coherent programming and policy recommendations are to be made.

\section{Subsistence farming and food security}

Many rural people in South Africa have diversified income sources, with a typically high dependency on state grants (Aliber and Hart 2009). When households were asked to identify their principal sources of monthly income in the study by De Cock et al. (2013), $75 \%$ of the respondents indicated that they received social grants from the State, ${ }^{7}$ while $31 \%$ received some kind of formal salary. Social grants were the most prevalent source of income across all districts. However, farming income and remittances were also recognised as an income source for $15 \%$ and $13 \%$ of households, respectively. This resonated with another study conducted in Limpopo where the direct value of small-scale farm production suggested that the contribution of lesser-grown crops and consumption during the growing season is often underestimated (Dovie et al. 2003).

Significantly, De Cock et al. (2013) noted that poor farmer households supplement food bought on the market by their own subsistence production, a point also emphasized by Vink (2012). Some $57 \%$ of the sampled households were involved in crop production, with maize being the most frequently grown (31\% of households), followed by mangos $(24.2 \%)$, spinach $(15.4 \%)$, paw-paws (papaya) (15.4\%) and tomatoes (14.2\%) (De Cock et al. 2013). Drawing on a broader set of studies, Pauw (2007) concluded that among these farming households, few earned sufficient from farming as a main source of income. Indeed, the Limpopo study revealed that all crops produced displayed a large average subsistence ratio (amount of production consumed/total production). The subsistence ratios tended to be largest for fruit $(87 \%)$, followed by staple crops $(55 \%)$ and vegetables $(54 \%)$. This indicates that, in general, people tend to produce fruit mainly for their own consumption, while for staple crops and vegetables households consume half of the production and the other half is sold.

\section{Wild vegetables and dietary diversity}

A second paper in this special section of Food Security picks up this theme. Mavengahama et al. (2013) argue that wild vegetables are an important source of food in the maize-based subsistence-farming sector of rural South Africa. Their main role is as an accompaniment to staple, cereal-based diets. They are generally reported to be rich in micronutrients, especially vitamin A, zinc, and iron, the principal nutrients which, when absent from the diet, result in 'hidden' hunger. Based on a review of published scientific articles on indigenous vegetables, the paper concludes that these vegetables generally have higher levels of various nutrients than the conventionally cultivated species.

\footnotetext{
${ }^{7}$ These consist mostly of old age pensions, child support grants, disability grants and veterans' grants.
} 
The paper also argues that although wild vegetables may be consumed in small quantities, they influence the intake of cereal staples, manage hunger and play a central role in household food security for the poorer rural groups. Indeed, mixing several wild variety species in one meal may contribute to dietary diversity in terms of more vegetable types as well as in terms of choice of relish. For some very poor families, wild vegetables are substitutes for certain food crops.

The use of wild vegetables is, however, not without significant challenges as it currently relies on harvesting without cultivation. This may be unsustainable in view of increasing population density, possible genetic erosion and loss of biodiversity. Kwapata and Maliro (1995) noted the decline in wild vegetable use due to chemical elimination as they are considered weeds. This is especially true where agricultural education in both commercial and communal areas is aimed at cash crop production through promotion of mono-cropping and mono-culture. An alternative to the subsistence approach to wild vegetable use is the integration of indigenous vegetables in cropping systems, which could result in increased agro-biodiversity.

A key question now being addressed by the research team is therefore whether wild vegetables can be successfully intercropped with other existing crops at the level of smallholder farming. Expectations about the future uses of wild vegetables - and smallholder agriculture in generalhave to be tempered by the reality of climate change. Regional food production is critically dependent on optimal local temperatures and precipitation, and any change outside the range of optimal conditions requires farmers to adapt their practices (Conway 2009; Nelson et al. 2009). Deviations from required conditions will inevitably pose major challenges to maintaining or increasing productivity based on a fragile ecosystem.

\section{Wildfowl as a source of protein}

A third study in this collection continues the theme of utilising wild sources of foods, in this case game birds as a viable source of meat (Geldenhuys et al. 2013). The authors argue that, in order to alleviate the current food security situation, it is essential to investigate meat sources which have the potential to be utilised sustainably. In contexts where a lack of protein intake contributes to malnutrition, access to the meat of "sport-hunted wildfowl" such as Egyptian geese (Alopochen aegyptiacus), Guinea fowl (Numida maleagris) and various wild pigeon breeds, with the aim of incorporating them into commercial markets, may be a viable food security strategy. In Zimbabwe for example, the guinea fowl is farmed extensively by local villagers and there is market potential for this species in developing countries (Madzimure et al. 2011).

However, before the utilisation of wildfowl meat can be realised, a number of challenges will have to be addressed, particularly if high quality meat is to be accessed. These include limited information on the quality of meat obtained from game birds, the handling practices during and after shooting activities, as well as potential farming possibilities. Areas warranting scientific research range from investigating the intrinsic and extrinsic factors that may have an influence on the ultimate quality of the meat to exploring possible techniques of improving its eating quality.

\section{Mariculture: a sustainable alternative?}

The fourth study in this collection continues the theme of alternative food sources in the context of the question of sustainability. The study notes the impact of worldwide declines in fish stocks on the livelihoods of coastal fishing communities as jobs are lost, and alternative forms of employment are limited. In response, mariculture (marine aquaculture) has been considered by governments to be a viable alternative to address unemployment and poverty in such communities. In Saldanha Bay in the Western Cape, the mussel and oyster industry can be expanded and has been identified as a means to alleviate poverty and enhance food security.

Against this backdrop, Olivier et al. (2013) examine the potential biological capacity of Saldanha Bay and the impact that expanded mariculture could have on employment creation if fully realised. Secondly, the authors assess the factors that affect the sustainable growth, development and employment creation potential of different mariculture ventures. Relating this to South Africa, five factors affecting the viability of this sector are analysed-namely the state, market, funding, natural environment and local community - to determine what the main factors are that inhibit the sector from reaching its full potential.

This interdisciplinary study, involving marine biologists and sociologists, suggests that Saldanha's bivalve mariculture sector is sustainable, but that its development, and hence the growth of its employment capacity, is limited by the regulatory environment, access to the international markets, and funding. Although South African government policies ostensibly support both mariculture and small businesses, the regulatory environment was more appropriate for a larger-scale industry, and too restrictive and expensive for the small, micro and medium enterprises currently dominating this 
sector in Saldanha Bay. In summary, regulatory constraints and economies of scale, coupled with a lack of surety arising from the nature of marine water leaseholds, mean that bivalve farms in Saldanha cannot generate sufficient capital to expand, nor can they easily secure loans from formal institutions. Thus, despite government objectives of supporting the sector, measures by the state are currently limiting its expansion.

Without state support, the sector has little scope to take advantage of a favourable market environment. Both the South African and international markets for oyster and mussel products are good despite the recent economic recession, although subsidised imports of mussels compete with local products and reduce profits within the sub-sector. Funding for the capital outlays required to increase production and improve economies of scale would improve competitiveness on local and international markets, but it is not readily available and is another constraint on expansion. Private investment and state assistance in the form of development grants and assistance during biotoxin closures, would allow this sector to expand. Currently, constant financial strain arising from the costly regulatory environment combines with periodic closures to reduce profits and hinder reinvestment within the industry.

Thus the conclusion is reached that the sector has great potential to expand and create employment, but is hampered by state legislation and regulations, access to the international market and the lack of financial investment.

\section{Conclusions}

The FSI at Stellenbosch University forms part of the strategic vision of the University to enhance its relevance and contribution to the needs and demands of Southern African society. As articulated in its establishment documents, the FSI is geared towards contributing to the emergence of a resilient, sustainable food system for the region, by reconceptualising the food security challenge, and creating new models of practice in the food system, through the integration of findings from in-depth research on key issues in the food value chain, collaboration across disciplinary boundaries, capacity building and systematic impact assessment. A major challenge facing the FSI is ensuring that its research is relevant to conditions in the food system, and that its findings contribute to policy change and action.

Clearly the challenges of reducing food insecurity in South Africa are different today from what they were in the past, as they are across Africa (Naylor 2011), requiring innovative responses and solutions that fundamentally reconsider the underpinnings of food insecurity and how to respond. To date initiatives have often been fragmented, piecemeal and difficult to bring to scale (Benson 2008). This cannot continue. As events in 2011 in North Africa have demonstrated, food issues, such as rising prices, can spark social unrest, destabilise fragile economies and wipe out years of development progress. Rising demand for food and fuel, coupled with resource depletion and inadequate governance of the global food system, has increased the fragility of the food economy, giving rise to calls for fundamental redesign of how food is produced, accessed and utilised (Foresight 2011).

In summary the paper has demonstrated a variety of perspectives on food security, highlighting how each aligns to a different dimension of the concept. Although these provide useful in-depth analyses of elements of food insecurity, it is argued that a more systemic approach that transcends disciplinary and sectoral boundaries is required to inform the emergence of a resilient food system for the $21^{\text {st }}$ century. A combination of rigorous disciplinary research with effective research-policy linkages and social learning is required. Mainstreaming such a transdisciplinary approach would be a key task of the FSI in the future. In partnership with government, business and civil society, universities such as Stellenbosch can play a key role in shifting the food system onto a more equitable and sustainable path, by harnessing existing and new scientific knowledge to accelerate institutional and technological innovation.

Conflict of interest The authors hereby declare that they have no conflicts of interest.

Open Access This article is distributed under the terms of the Creative Commons Attribution License which permits any use, distribution, and reproduction in any medium, provided the original author(s) and the source are credited.

\section{References}

Aliber, M., \& Hart, T. G. (2009). Should subsistence agriculture be supported as a strategy to address rural food insecurity? Agrekon, 48(4), 434-458.

Altman, M., Hart, T. G., \& Jacobs, P. T. (2009). Household food security status in South Africa. Agrekon, 48(4), 345-361.

Ardington, C., \& Case, A. (2009). National income dynamics study (NIDS). Health: analysis of the NIDS wave 1 dataset. Discussion paper no. 2. South Africa: The Presidency Republic of South Africa and SALDRU. Retrieved 21 October 2012 from http:// www.nids.uct.ac.za/home/index.php?/Nids-Documentation/ discussion-papers.html.

Benson, T. (2008). Improving nutrition as development priority. Addressing undernutrition in national policy processes in Sub-Saharan Africa. Research Report 156. Washington DC: International Food Policy Research Institute.

Chabane, C. (2012). Media statement by Minister in The Presidency for Performance Monitoring and Evaluation, Collins Chabane on the release of the Mid-Term Review. Retrieved 1 June 2012 from http://www.thepresidency.gov.za/pebble.asp?relid=6156.

Chopra, M., Witten, C., \& Drimie, S. (2009). Combating malnutrition in South Africa. Global alliance for improved nutrition (GAIN) Working 
Paper Number 1. Retrieved 29 August, 2012 from www.gainhealth. org/sites/default/files/Working\%20Paper\%20Series/.

Conway, G. (2009). The science of climate change in Africa: impacts and adaptation. London: Grantham Institute for Climate Change, Imperial College. Discussion Paper No. 1.

Crush, J., \& Frayne, B. (2010). The invisible crisis: urban food security in Southern Africa, Urban food Security Series No. 1. Kingston: African Food Security Urban Network, Queen's University.

De Cock, N., d'Haese, M., Vink, N., et al. (2013) Food security in the rural areas of the Limpopo province. Food Security, 5(2), doi:10.1007/s12571-013-0247-y.

Dovie, D. B. K., Witkowski, E. T. F., \& Shackelton, C. M. (2003). Direct-use value of smallholder crop production in a semi-arid rural South African village. Agricultural Systems, 76, 337-357.

Drimie, S., \& Casale, M. (2009). Multiple stressors in Southern Africa: the link between HIV/AIDS, food insecurity, poverty and children's vulnerability now and in the future. AIDS Care, 21(S1), 28-33.

Du Toit, A. (2011). Why growth in South Africa has not been (that) good for the poor. De-agrarianization, adverse incorporation and structural inequality in the aftermath of Apartheid. Paper prepared for the 2011 PEGNET Conference. Hamburg: German Institute of Global and Area Studies.

Foresight. (2011). The future of food and farming. Final project report. London: Government Office for Science.

Geldenhuys, G., Hoffman, L., \& Muller, N. Gamebirds. (2013) A sustainable food source in Africa? Food Security, 5(2), doi:10.1007/s12571-013-0245-0.

Godfray, H. C., Beddington, J. R., Crute, I. R., Haddad, L., Lawrence, D., et al. (2010). Food security: the challenge of feeding 9 billion people. Science, 327, 812-818.

Greenberg, S. (2006). Urban food politics, welfare and resistance: a case study of the Southern Johannesburg metro. CCS grant report. Pietermaritzburg: University of KwaZulu-Natal.

Hammond, R. A., \& Dubé, L. (2012). A systems science perspective and transdisiciplnary models for food and nutrition security. PNAS, 109(3), 12356-12363. Accessed 12 September 2012 from http://www.pnas.org/content/109/31/12356.full.

Hirsch Hadorn, G., Biber-Klemm, S., Grossenbacher-Mansuy, W., Hoffmann-Riem, H., Joye, D., et al. (2008). The emergence of transdisciplinarity as a form of research. In G. Hirsch Hadorn, H. Hoffmann-Riem, S. Biber-Klemm, W. Grossenbacher-Mansuy, D. Joye, et al. (Eds.), Handbook of transdisciplinary research (pp. 19-39). Berlin: Springer Press.

Hunter, N., May, J., \& Padayachee, V. (2003). Lessons for PRSP from poverty reduction strategies in South Africa. Working paper no. 39. Pietermaritzburg: School of Development Studies, University of KwaZulu-Natal.

International Assessment of Agricultural Knowledge (IAASTD). (2009). Agriculture at a crossroads. Global report, Chapters 1, 4, Island Press. Retrieved 2 September 2012 from http://www. agassessment.org/reports/iaastd/en/agriculture $\% 20 \mathrm{at} \% 20 \mathrm{a} \% 20$ crossroads_synthesis\%20report\%20(english).pdf.

International Food Policy Research Institute. (1995). A 2020 vision for food, agriculture, and the environment: the vision, challenge, and recommended action. Washington, DC: IFPRI.

Jacobs, P. T. (2009). The status of household food security targets in South Africa. Agrekon, 48(4), 410-433.

Jacobs, P. (2010). Household food insecurity, rapid food price inflation and the economic downturn in South Africa. Agenda, 35, 38-51.

Jahn, T. (2008). Transdisciplinarity in the practice of research. In M. Bergmann \& E. Schramm (Eds.), Transdisziplinare Forschung. Integrative Forschungprozesse verstehen und bewerten (pp. 2137). Frankfurt: Campus Verlag.

Kwapata, M.P., \& Maliro, M.F. (1995). Indigenous vegetables in Malawi: germplasm collecting and improvement of production practices. Paper presented at the workshop "Genetic Resources of Traditional Vegetables in Africa. Options for Conservation and Use", 29-31 August 1995, Nairobi Kenya. Retrieved 1 September, 2012 from http://www.biodiversityinternational.org/publications.

Labadarios, D., Swart, R., Maunder, E. M. W., Kruger, H. S., Gericke, G. J., et al. (2008). Executive summary of the National Food Consumption Survey Fortification Baseline (NFCS-FB-I) South Africa. South African Journal of Clinical Nutrition, 21(2), 245-300.

Madzimure, J., Saina, H., \& Ngorora, G. P. K. (2011). Market potential for guinea fowl (Numidia meleagris) products. Tropical Animal Health and Production, 43, 1509-1515.

Mavengahama, S., McLachlan, M., \& de Clercq, W. (2013). The role of wild vegetable species in household food security in maize based subsistence cropping systems. Food Security, 5(2), doi:10.1007/s12571-013-0243-2.

McLachlan, M., \& Thorne, J. (2009). Development planning division working paper series, No 16. Midrand: DBSA.

National Planning Commission. (2012). National development plan 2030. Retrieved 5 September 2012 from http://www.info.gov.za/ issues/national-development-plan/index.html.

Naylor, R. (2011). Expanding the boundaries of agricultural development. Food Security, 3, 233-251. doi:10.1007/s12571-011-0123-6.

Nelson, G. C., Rosegrant, M. W., Koo, J., Robertson, R., Sulser, T., Zhu, T., et al. (2009). Climate change: impact on agriculture and costs of adaptation. Food policy report. Washington, D.C.: International Food Policy Research Institute.

Olivier, D., Heinecken, L., \& Jackson, S. (2013). Mussel and oyster culture in Saldanha Bay, South Africa: potential for sustainable growth, development and employment creation. Food Security, 5 (2), doi:10.1007/s12571-013-0244-1.

Pauw, K. W. (2007). Agriculture and poverty: farming for food or farming for money? Agrekon, 46(2), 195-218.

Puoane, T., Steyn, K., Bradshaw, D., Laubscher, R., Fourie, J., et al. (2002). Obesity in South Africa: the South African demographic and health survey. Obesity Research, 10, 1038-1048.

Ramalingam, B., Jones, H., Reba, T., \& Young, J. (2008). Exploring the science of complexity: ideas and implications for development and humanitarian efforts, Overseas Development Institute, Working Paper 285. Retrieved October 2010 from http://www.odi.org.uk.

Regeer, B., \& Bunders, J. (2009). Knowledge co-creation: interaction between science and society - a transdisciplinary approach to complex, societal issues. Holland: Athena Institute, VU University Amsterdam.

Royal Society. (2009). Reaping the benefits: science and the sustainable intensification of global agriculture, 1-10, 4750. Retrieved 2 September 2012 from http://royalsociety.org/ Reapingthebenefits.

Rule, S., Aird, R., Drimie, S., Faber, M., Germishuyse, T., et al. (2005). Report on survey in Sekhukhune to pilot the development of a food insecurity and vulnerability modelling system (FIVIMS) for South Africa. Pretoria: Human Sciences Research Council for the FIVIMS Consortium.

StatsSA. (2012). GHS Series, Volume IV, Food security and agriculture, 2002-2011. Pretoria: Statistics South Africa.

Thompson Klein, J., Grossenbacher-Mansuy, W., et al. (2001). Transdisciplinarity: joint problem solving among science, technology, and society. An effective way for managing complexity. Basel: Birkhauser.

Uthman, O.A., \& Aremu, O. (2008). Malnutrition among women in Sub-Saharan Africa: rural-urban disparity. Rural Remote Health, 8, 931. Retrieved 2 September 2012 from http://www.rrh.org.au/ publishedarticles/article print 931.pdf.

Vearey, J., Palmary, I., Thomas, L., Nunez, L., \& Drimie, S. (2010). Urban health in Johannesburg: the importance of place in understanding intra-urban inequalities in the context of migration and HIV. Health \& Place, 16(4), 694-702. 
Vink, N. (2012). Food security and African agriculture. South African Journal of International Affairs, 19(2), 157-177. doi:10.1080/ 10220461.2012.706489.

Vogel, C., Moser, S., Kasperson, R., \& Dabelko, G. (2007). Linking vulnerability, adaptation, and resilience science to practice: pathways, players, and partnerships. Global Environmental Change, 17, 349-364.

WHO. (2012). Fact sheet 311. http://www.who.int/mediacentre/ factsheets/fs311/en/. Accessed 21 Oct 2012.

World Bank. (2008). World development report 2008: agriculture for development. Washington: World Bank.

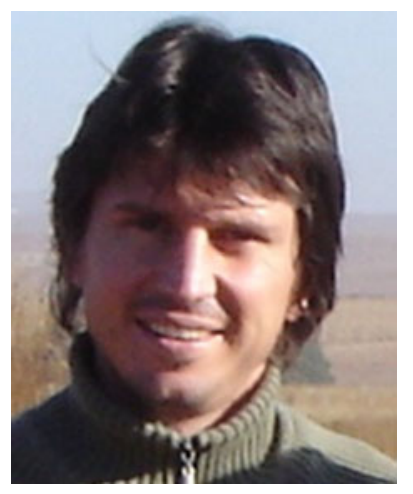

Scott Drimie leads a research and facilitation consultancy that focuses on food security, food systems and livelihood issues in Southern Africa. The company consults for various public and private sector organisations. He is an Extraordinary Associate Professor at Interdisciplinary Health Sciences at Stellenbosch University as well as an Extraordinary Senior Lecturer at the School of Public Management and Planning. He chairs the Advisory Board of the University's Food Security Initiative.

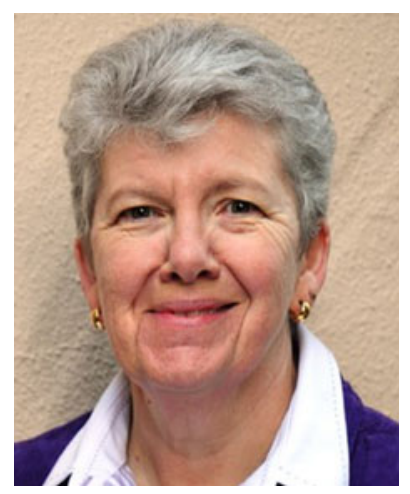

Milla McLachlan has been involved in international social development for more than 30 years, focusing on addressing food and nutrition issues though public policy, public-private partnerships and community action. Among other roles, she served as Principal Policy Analyst on poverty and social issues at the Development Bank of Southern Africa, and as Nutrition Advisor in the World Bank in Washington DC. Since her return to South Africa in 2006, Milla has consulted widely in Africa, building capacity for community-based action on nutrition, and facilitating leadership and partnership building activities. With a particular interest in social change as it relates to food systems, Milla now enjoys navigating the interface between research, policy and practice through her leadership and involvement in the SU Food Security Initiative (FSI), the Community Nutrition Security Project of the SU Division of Human Nutrition, and the Southern African Food Lab, a multi-stakeholder initiative using social innovation to shift the food system towards greater sustainability.

Prof. McLachlan holds a PhD and MA from Michigan State University, and an MA in Transpersonal Psychology (Ecopsychology) from Naropa University. She has published several peer-reviewed journal articles, book chapters and reviews, and co-edited Combating Malnutrition: Time to Act, a World Bank publication on nutrition change strategies. 